\title{
IMPLEMENTASI DAN PERANCANGAN APLIKASI PADA PERENCANAAN BANTALAN DAN BEARING
}

\author{
Asrul Sudiar(1) \\ asrulsudiar@poliban.ac.id
}

(1) Staf Pengajar Progam Studi Teknik Alat Berat Politeknik Negeri Banjarmasin

\begin{abstract}
Ringkasan
Perkembangan teknologi sudah demikian pesatnya, berbagai inovasi dilakukan agar proses pembuatan dan pengembangan suatu produk semakin mudah. Pada lingkup perguruan tinggi, matakuliah Elemen Mesin merupakan salah satu matakuliah wajib di Jurusan Teknik Mesin. Namun pada kenyataannya, kemampuan para praktisi dan mahasiswa untuk memahami dan menguasai perencanaan elemen mesin masihlah sangat rendah. Diperlukan suatu upaya dan alat bantu dalam memahami dan merancang suatu produk dari proses perencanaan sampai proses perhitungan yang mudah, cepat dan interaktif sehingga akan membantu siapa saja baik praktisi maupun mahasiswa jurusan Teknik Mesin dalam merancang dan merencanakan suatu produk berdasarkan perhitungan elemen mesin yang benar, dimana perhitungan ini berdasarkan pada perhitungan dan perencanaan elemen mesin yang diajarkan di Jurusan Teknik Mesin.
\end{abstract}

Hasil penelitian ini berupa aplikasi software engineering yang nantinya diharapkan akan membantu mahasiswa Teknik Mesin dalam memahami dan melakukan proses perhitungan dengan benar sesuai diagram alir perhitungan elemen mesin yang benar, sehingga diharapkan akan ikut memberi pengaruh pada pemahaman proses perkuliahan matakuliah di Jurusan Teknik Mesin. Aplikasi ini juga memiliki keunggulan diantaranya memiliki kemampuan reset terhadap input yang bervariasi, kemampuan menyimpan hasil perhitungan dalam bentuk file output, meminimalkan input parameter yang salah, menampilkan pesan hasil perhitungan yang tidak aman, serta memberikan hasil perhitungan yang cepat dan akurat

\section{PENDAHULUAN}

Seiring perkembangan jaman, berbagai
jenis dan bentuk industri yang
mempergunakan dan menghasilkan mesin di
Indonesia, maka semakin banyak diperlukan
tenaga ahli yang mampu mengatasi berbagai
masalah di bidang perbaikan dan
perencanaan mesin. Namun justru dalam
keadaan yang demikian itu saat ini dirasakan
adanya kelemahan dalam pengetahuan-
pengetahuan dasar mesin pada para teknisi
yang bergerak dalam bidang permesinan,
sehingga perlu adanya pemahaman terhadap
suatu ilmu pengetahuan dibidang elemen
mesin ini yang dapat memberikan pedoman
dalam merencanakan dan memilih elemen
mesin.

Dilingkup pendidikan perguruan tinggi, khususnya di fakultas / jurusan teknik mesin terdapat matakuliah wajib yang mempelajari pengetahuan dasar mesin, yang menjadi panduan dasar bagi mahasiswa teknik mesin untuk mempelajari cara memilih dan merencanakan elemen mesin yaitu matakuliah elemen mesin I, II dan III. Namun pada kenyataannya tingkat pemahaman dari mahasiswa dalam menguasai dan melakukan perencanaan elemen mesin masih sangat rendah, ini dapat dilihat dari sangat sedikitnya mahasiswa teknik mesin yang mampu melakukan perhitungan dalam perencanaan elemen mesin dengan baik dan benar.

Diperlukan suatu metode atau alat bantu yang dapat meningkatkan pemahaman mahasiswa teknik mesin terhadap matakuliah elemen mesin ini. Metode yang selama digunakan dalam proses pembelajaran matakuliah elemen mesin adalah sebuah metode konvensional, dimana pengajar / dosen menerangkan dan menjelaskan alur perencanaan dan perhitungan komponen mesin yang disampaikan dari awal input data, pemilihan bahan, pertimbangan faktor koefisien, penggunaan persamaan rumus, pertimbangan dari tabel yang relevan serta pemeriksaan faktor keamanan sampai didapat hasil output dari proses perencanaan komponen, semua dilakukan dengan menulisnya di papan sehingga terkesan sulit untuk dipahami.

Berdasarkan masalah tersebut maka peneliti merasa tertarik untuk mengembangkan suatu produk alat bantu 
berupa sebuah aplikasi perencanaan elemen mesin yang terdiri dari beberapa form perhitungan elemen mesin yang dibuat berbasis GUI (Graphical User Interface) dimana program aplikasi ini dibuat berdasarkan diagram alir atau flowchart perhitungan elemen mesin karya buku Profesor Kiyokatsu Suga dan Sularso, MSME yang dilengkapi dengan tampilan tabel dan grafik sehingga dapat meningkatkan efektifitas pemahaman mahasiswa teknik mesin maupun para praktisi mesin yang bergerak dibidang perencanaan elemen mesin. Berdasarkan hal tersebut maka peneliti tertarik untuk melakukan penelitian ini.

\section{TUJUAN PENELITIAN}

Berdasar pada permasalahan diatas, peneliti merumuskan beberapa tujuan yang ingin dicapai dalam penelitian ini yaitu:

- Meningkatkan efisiensi metode pembelajaran pada matakuliah elemen mesin dengan mengembangkan suatu aplikasi yang interaktif pada perencanaan elemen mesin, khususnya pada perhitungan bearing berbasis GUI (Graphical User Interface) dengan compiler Delphi

- Melakukan implementasi dan pengembangan alat bantu perencanaan elemen mesin berbasis GUI (Graphical User Interface) di Laboratorium Teknik Mesin

\section{METODE PENELITIAN}

Metode penelitian yang digunakan pada penelitian ini merupakan metode ActionResearch(AR) atau Penelitian Tindakan yang bertujuan untuk meningkatkan metode / cara praktisi dan dosen pengajar dalam proses mengajar di lingkungan kampus sehingga diharapkan dapat meningkatkan pemahaman mahasiswa terhadap perhitungan dan perencanaan elemen mesin.

Tahapan dalam metode penelitian ini meliputi studi literatur, penguasaan dan pemahaman perhitungan pada perancangan komponen elemen mesin, perancangan interface program, penulisan kode program, kompilasi program, validasi program, finishing program sampai pada implementasi program.Pada penelitian ini diperlukan adanya alur penelitian untuk menampilkan permasalahan (Effect) yang dihadapi dan kemungkinan penyebab-penyebabnya (Cause) yang digambarkan dalam bentuk
Fishbone Diagram. Adapun diagram Fishbone yang menunjukkan permasalahan utama dari apa yang dilaksanakan pada penelitian ini, beserta beberapa kemungkinan penyebabnya yaitu sbb :

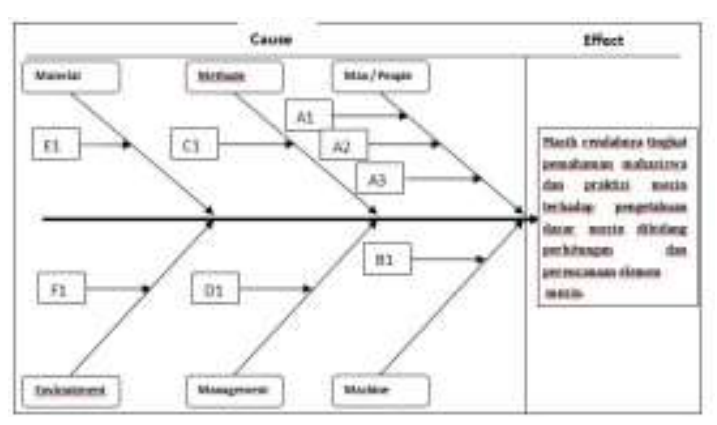

Gambar 1. Fishbone Diagram Penelitian

Keterangan ( Legend) dari FishBone Diagram Tersebut

Man :

- $(\mathrm{A} 1)=$ Kurang menguasai perencanaan elemen mesin, sesuai flowchart perencanaan yang terdapat pada buku panduan elemen mesin.

- $(\mathrm{A} 2)=$ Kurang efektifnya cara yang digunakan oleh praktisi teknik mesin maupun mahasiswa dalam menghitung perencanaan elemen mesin.

- $(\mathrm{A} 3)=$ Tidak mengetahui cara membuat aplikasi berbasis pemrograman GUI sebagai alat bantu perencanaan elemen mesin.

Machine :

- $(B 1)=P C$ authoring yang digunakan dilingkungan pengajaran matakuliah pemrograman komputer, belum diarahkan konsep pemrogramannya untuk membuat aplikasi teknik mesin seperti perhitungan elemen mesin ini.

Methode :

- $\quad(\mathrm{C} 1)=$ Metode pengajaran yang digunakan untuk perencanaan elemen mesin pada matakuliah elemen mesin I, II dan III masih menggunakan metode konvensional yang dirasa kurang efektif dalam menerangkan alur perhitungan / flowchart perencanaan elemen mesin.

Management :

- $\quad(D 1)=$ Belum adanya inisiatif dari pengajar maupun pembuat kebijakan di Jurusan berkaitan dengan penerapan konsep keilmuan matakuliah pemrograman 
computer kearah penerapan aplikasi bidang teknik mesin.

Material :

- $(E 1)=$ Tidak adanya panduan dalam bentuk Manual Book yang memberikan tutorial cara merancang aplikasi pemrograman teknik berbasis GUI dengan Compiler Delphi untuk diterapkan dalam perhitungan perencanaan elemen mesin.
Environtment :

- $(F 1)=$ Budaya lingkungan yang belum mengenal alat bantu berupa aplikasi perhitungan dan perencanaan teknik berbasis pemrograman GUI sebagai media pembelajaran yang sangat efektif dalam menguasai perencanaan elemen mesin.

\section{DIAGRAM ALIR PENELITIAN}

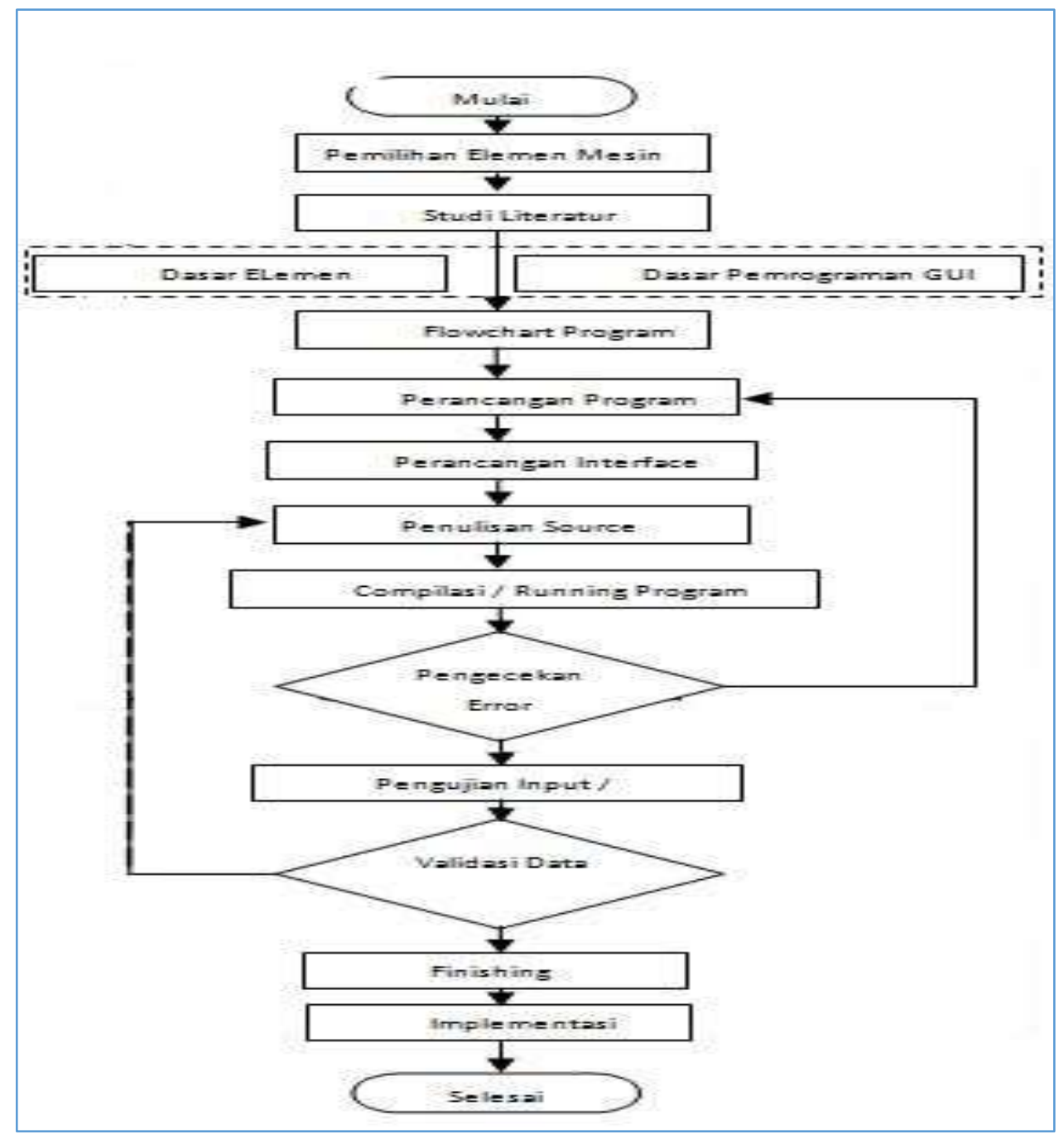

Gambar 2. Diagram Alir Penelitian

\section{HASIL DAN PEMBAHASAN}

Pada suatu kegiatan perancangan perangkat lunak atau software perlu memahami tahapan-tahapan yang perlu dikerjakan terlebih dahulu, sebelum nantinya peneliti mulai merancang seperti ditunjukkan pada diagram alir penelitian pada bab 3 sebelumnya, ini karena software yang dibuat atau dirancang nantinya merupakan software dibidang engineering khususnya perhitungan elemen mesin, sehingga perlu terlebih dahulu memahami dan menguasai literature pada perhitungan elemen mesin sebelum membuat program. 


\section{Diagram Alir Perhitungan Bearing}

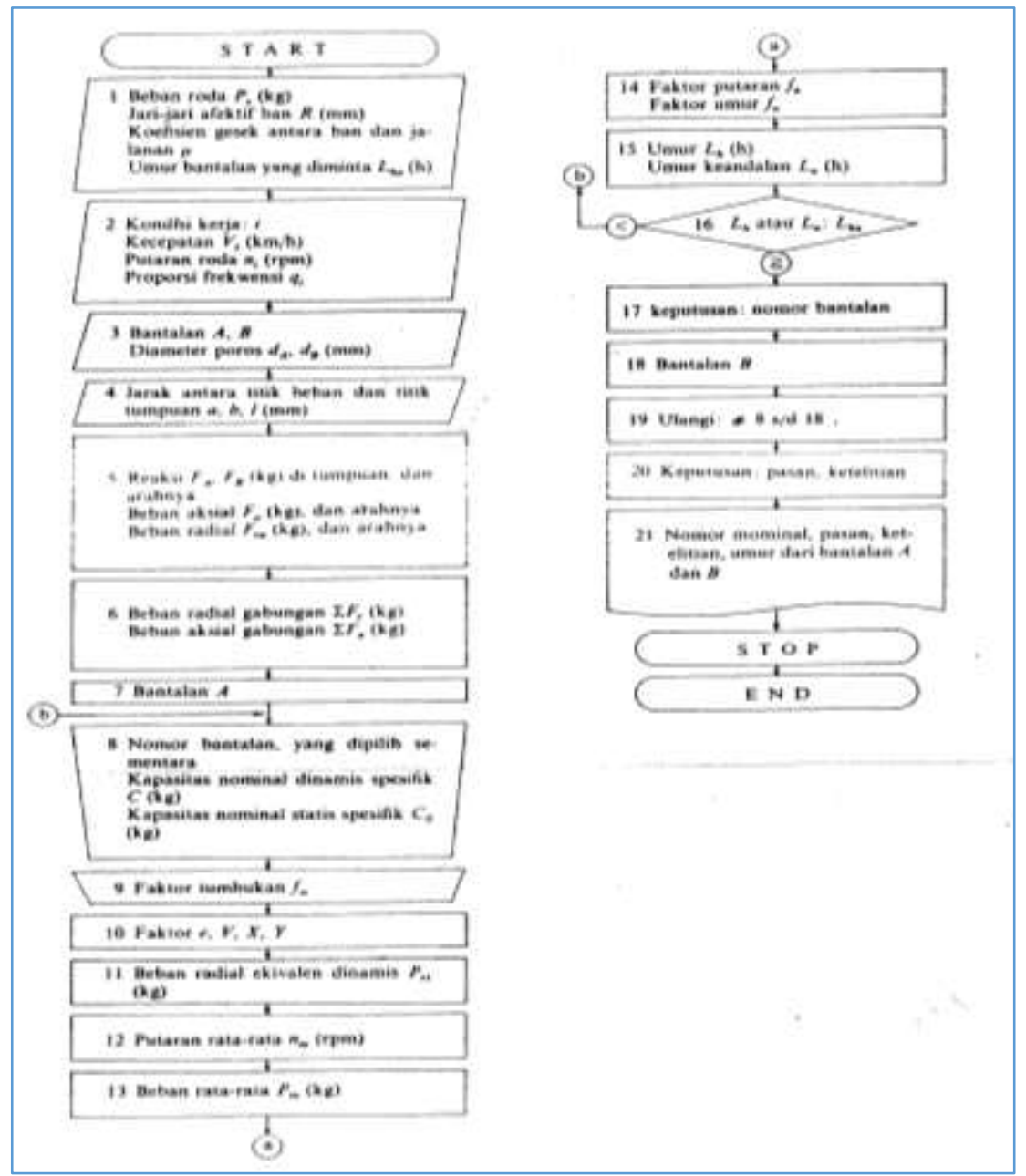

Gambar 3. Diagram Alir Perhitungan Bearing

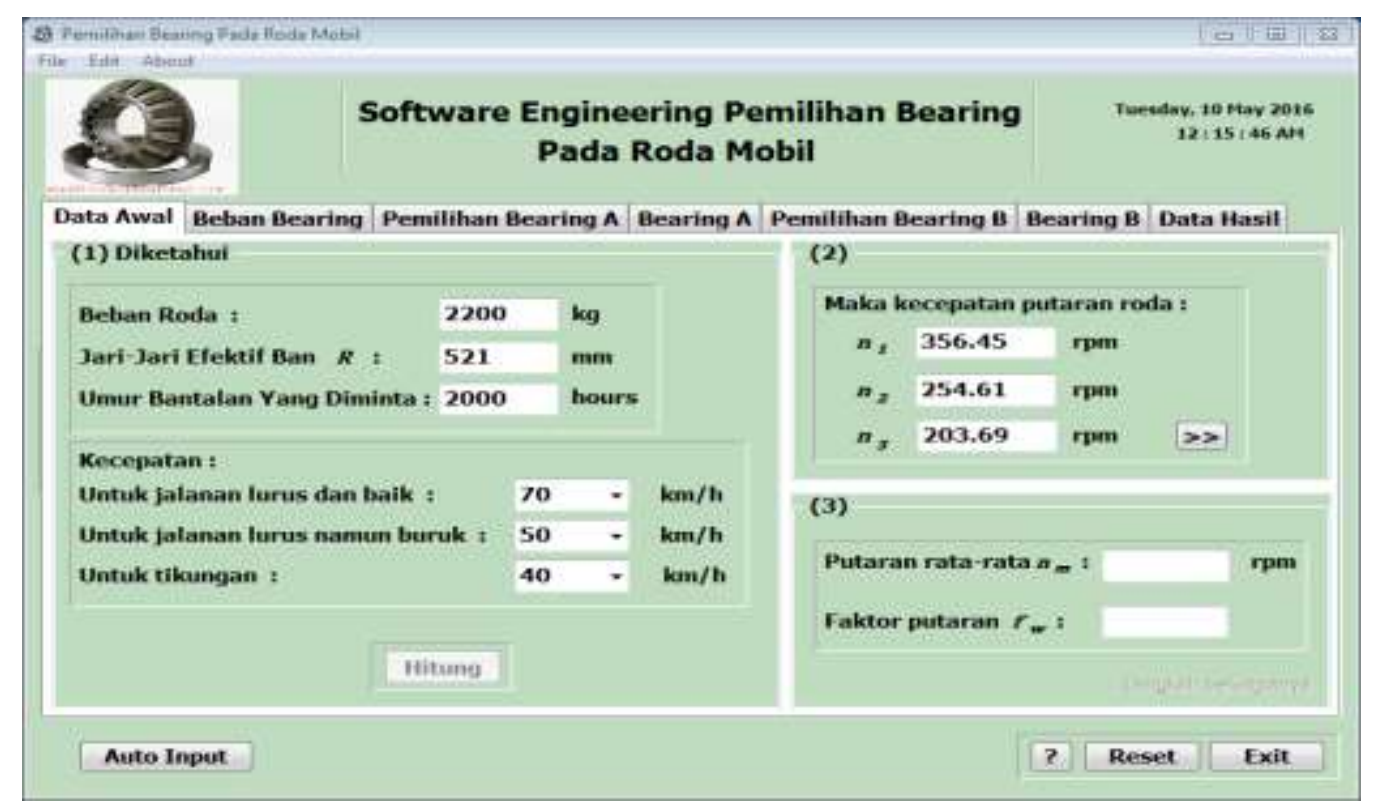

Gambar 4. Form Perhitungan Data Awal 


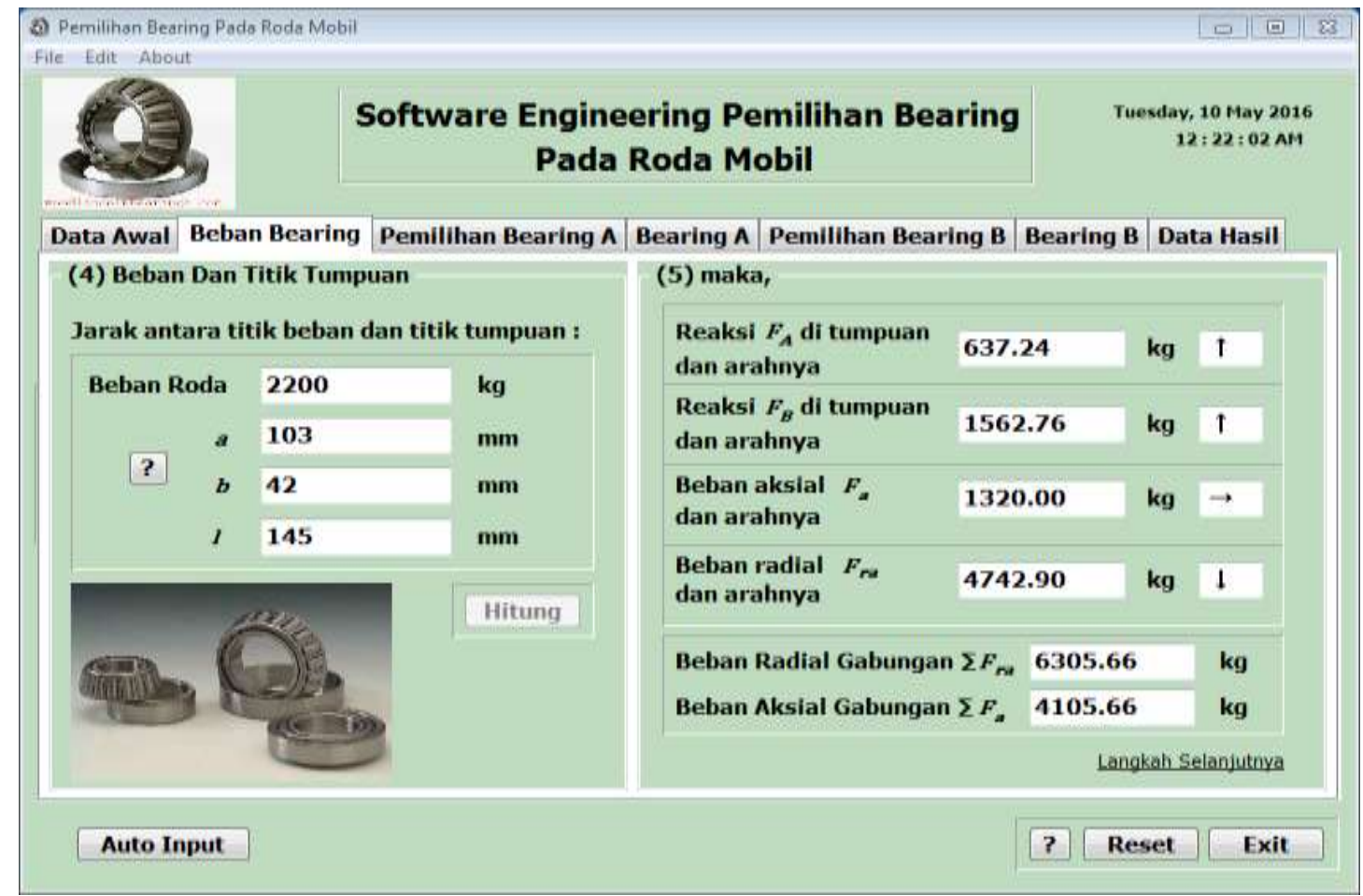

Gambar 5. Form Perhitungan Beban Bearing

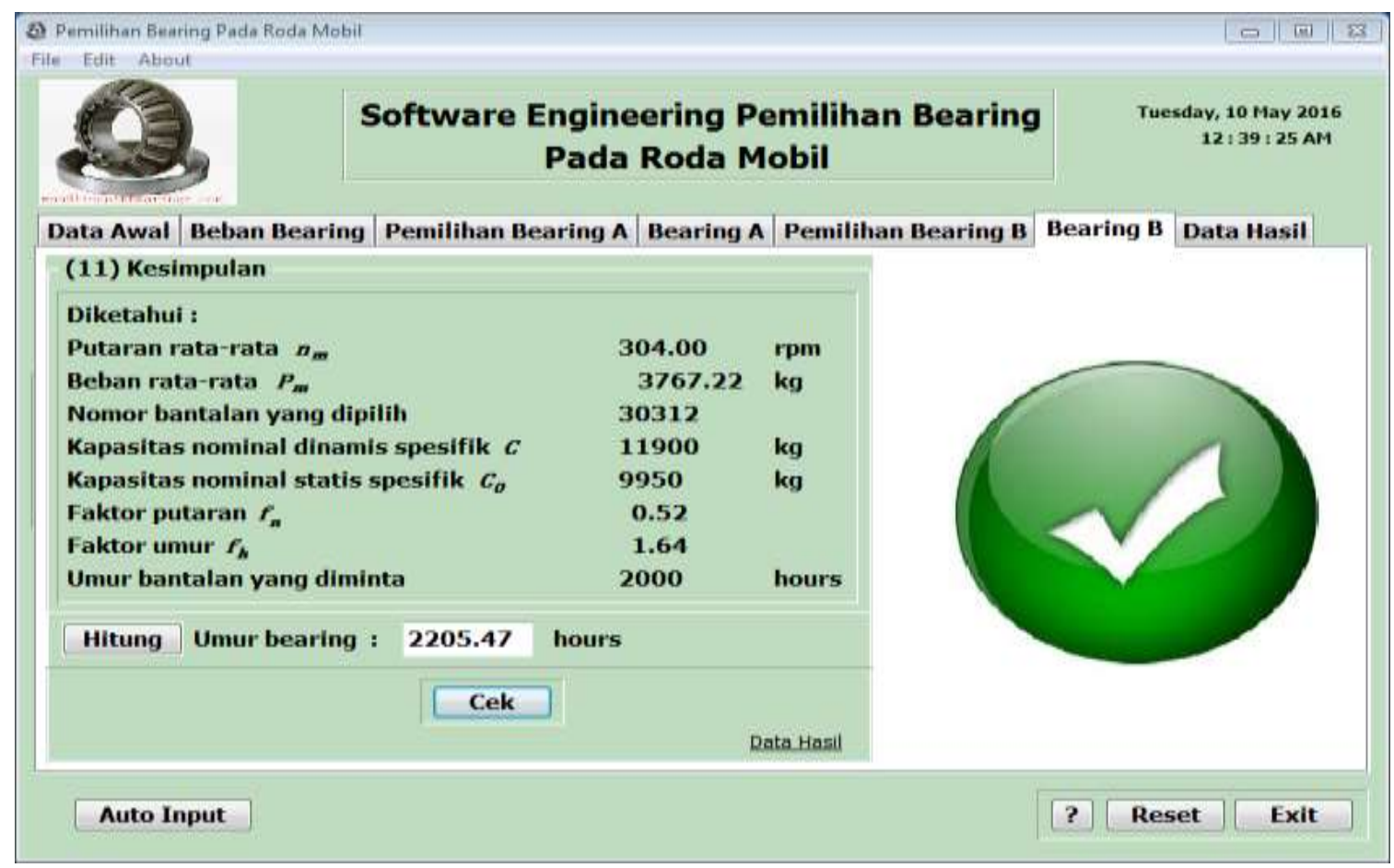

Gambar 6. Form Perhitungan Bearing B 


\section{KESIMPULAN}

Pada akhir penelitian ini, peneliti berusaha merangkum apa yang telah peneliti lakukan dalam proses perancangan software engineering untuk perhitungan elemen mesin ini dengan menggunakan compiler Delphi, sekaligus bagaimana implementasinya oleh para praktisi maupun mahasiswa dilingkup Jurusan Teknik Mesin sbb:
Terjadi peningkatan pemahaman, penguasaan materi dan ketertarikan minat praktisi maupun mahasiswa pada matakuliah elemen mesin dengan menggunakan alat bantu software engineering pada perhitungan bearing ini. Beberapa hal yang menjadi keunggulan dari software ini dibanding menggunakan metode manual adalah

Tabe1. Hasil Implementasi Program

\begin{tabular}{|c|l|l|l|}
\hline No. & \multicolumn{1}{|c|}{ Fitur } & \multicolumn{1}{c|}{ Cara Manual } & \multicolumn{1}{c|}{ Using Software } \\
\hline 1 & $\begin{array}{l}\text { Kecepatan proses } \\
\text { perhitungan elemen mesin } \\
\text { sampai didapat data hasil. }\end{array}$ & $>75$ menit & menit \\
\hline 2 & Ketepatan Hasil & Sering Tidak Akurat & $100 \%$ Akurat \\
\hline 3 & Ketertarikan / minat & $\begin{array}{l}\text { Kurang menarik dan } \\
\text { cenderung membosankan }\end{array}$ & Interaktif dan Menarik \\
\hline 4 & Pemahaman thd proses & Sulit dipahami mahasiswa & Mudah dipahami \\
\hline 5 & $\begin{array}{l}\text { Kemudahan dalam mencari } \\
\text { nilai pada diagram }\end{array}$ & $\begin{array}{l}\text { Sulit bergantung pada } \\
\text { buku literatur }\end{array}$ & $\begin{array}{l}\text { Mudah karena Diagram } \\
\text { telah terintegrasi pada } \\
\text { software }\end{array}$ \\
\hline 6 & $\begin{array}{l}\text { Kemudahan dalam mencari } \\
\text { nilai pada table }\end{array}$ & $\begin{array}{l}\text { Sulit bergantung pada } \\
\text { buku literatur }\end{array}$ & $\begin{array}{l}\text { Mudah karena Tabel telah } \\
\text { terintegrasi pada software }\end{array}$ \\
\hline 7 & $\begin{array}{l}\text { Kemudahan dalam mencari } \\
\text { koreksi dari nilai yang } \\
\text { diinputkan. }\end{array}$ & $\begin{array}{l}\text { Sulit bergantung pada } \\
\text { buku literatur }\end{array}$ & $\begin{array}{l}\text { Mudah karena Faktor } \\
\text { Koreksi dan Keamanan } \\
\text { telah terintegrasi pada } \\
\text { software }\end{array}$ \\
\hline 8 & $\begin{array}{l}\text { Dokumentasi Hasil } \\
\text { Perhitungan }\end{array}$ & $\begin{array}{l}\text { Manual menggunakan } \\
\text { kertas / buku }\end{array}$ & $\begin{array}{l}\text { Otomatis tersimpan } \\
\text { dalam bentuk File data } \\
\text { yang siap diprint }\end{array}$ \\
\hline
\end{tabular}

\section{DAFTAR PUSTAKA}

[1] Jocelyn Armarego, 2009, "Advanced Software Design: a Case in Problembased Learning", School of Engineering, Murdoch University, Western Australia.

[2] Hong Zhang and Charles Lemckert, 2014, "How to teach first-year engineering students to learn computing and programming effectively?", Griffith School of Engineering, Griffith University.

[3] Frey, D.D., and X.Li, 2007, "Software Design of Machine Element Using Hierarchical Probability Models to Evaluate Parameter Design Methods", Journal Of Quality Technology, 40(1):119.

[4] Kiyokatsu Tsuga, Sularso, 2004, "Dasar Perencanaan dan Pemilihan Elemen
Mesin”, Penerbit PT. Pradya Paramita, Jakarta

[5] Jogiyanto, HM Ph.D, 1989, "Teori dan Aplikasi Program Komputer Bahasa Pascal Termasuk Database Toolbox ", Penerbit Andi Offset, Yogyakarta

[6] Abdul Kadir, 2003, " Dasar Pemrograman Delphi ", Penerbit Andi Offset, Yogyakarta

[7] Rahmat Putra, 2003, "The Best Source Code For Interactive Programs ", Penerbit PT. Elex Media, Jakarta

[8] Surya Dharma, MPA., Ph.D, (2008), Pendekatan, Jenis, Dan Metode Penelitian Pendidikan : Jakarta 